Participation of Parents in I mproving the Quality of Education in MI Assa'adah Labuapi, West Lombok Regency, West Nusa Tenggara Province

\title{
Partisipasi Orang Tua Murid dalam Meningkatkan Kualitas Pendidikan MI Assa'adah Labuapi Kabupaten Lombok Barat Provinsi Nusa Tenggara Barat
}

\author{
Mastu $\mathbf{r}^{3}$ \\ email: mastur1234@gmail.com
}

\begin{abstract}
This study aims to determine; 1). How parents' participation in improving the quality of Education in MI Assa'adah Labuapi, West Lombok Regency 2019-2020 Academic Year, 2). Want to know what obstacles are faced in improving the quality of Education in Ml Assa'adah Labuapi, West Lombok Regency, Academic Year 2019-2020. Data collection methods that the authors use in this study are, the Observation Method (observation), Interview Method (Interview), and the Documentation Method. MI Assa'adah Labuapi, West Lombok, is considered quite successful in making people aware of the importance of participating in carrying out the education of their children, from the research results obtained 1). Parental participation such as helping to improve madrasas, whether in the form of assistance with energy, money or other building materials, besides that parents also help children learn at home by meeting the needs of their children and guiding learning, 2). The obstacle faced by Ml Assa'adah Labuapi West Lombok is the number of teachers that are not balanced with the number of students because there is only one teacher from the country besides honorary teachers, inadequate facilities and infrastructure such as benches, some is slightly damaged and the condition of the room has not been well organized. and the hall is still joined by other institutions.
\end{abstract}

\begin{abstract}
Abstrak: Penelitian ini bertujuan untuk mengetahui; 1). Bagaimana partisipasi orang tua murid dalam meningkatkan kualitas Pendidikan di Ml Assa'adah Labuapi Kabupaten Lombok Barat Tahun Pelajaran 2019-2020, 2). Ingin mengetahui kendala-kendala apa yang dihadapi dalam meningkatkan kualitas Pendidikan di MI Assa'adah Labuapi Kabupaten Lombok Barat Tahun Pelajaran 2019-2020. Metode Pengumpulan Data yang penulis gunakan dalam penelitian ini adalah, Metode Observasi (pengamatan), Metode Wawancara (Interview), dan Metode Dokumentasi. Ml Assa'adah Labuapi Lombok Barat,
\end{abstract}

${ }^{3}$ Dosen Tetap STIT Darussalimin NW Praya Lombok Tengah Provinsi Nusa Tenggara Barat 
dinilai cukup berhasil dalam menyadarkan masyarakat sebagaimana arti pentingnya berpartisipasi untuk melaksanakan pendidikan putraputrinya mereka, dari hasil penelitian diperoleh 1). Partisipasi orang tua seperti membantu perbaikan madrasah, baik itu berupa bantuan tenaga, uang atau bahan-bahan bangunan lainnya, selain itu orang tua juga membantu anak-anak belajar di rumah dengan memenuhi kebutuhan anak-anak mereka serta membimbing belajar, 2). Kendala yang dihadapi oleh Ml Assa'adah Labuapi Lombok Barat adalah jumlah guru yang tidak seimbang dengan jumlah murid karena guru negerinya hanya satu orang selainnya guru honorer, sarana dan prasarana kurang memadai seperti bangku sebagian ada yang rusak ringan dan keadaan ruangan belum tertata dengan baik mushalla dan aula masih bergabung dengan lembaga lainnya.

Keywords: Parental Participation, Quality of Education

Kata kunci: Partisipasi Orang Tua, Kualitas Pendidikan

\section{A. Latar Belakang Masalah}

Melalui pelibatan masyarakat dalam pengelolaan sekolah, maka pemerintah akan terbantu, baik dalam control maupun pembayaran, artinay bahwa dalam dunia pendidikan partisipasi masyarakat merupakan faktor yang sangat menentukan berlangsungnya program pendidikan. Perlunya memberdayakan lingkungan sekolah dan masyarakat secara optimal karena sekolah memerlukan masukan dari masyarakat dalam menyusun program yang relevan, sekaligus memerlukan dukungan masyarakat dalam melaksanakan program tersebut.

Partisipasi masyarakat dalam dunia pendidikan, khususnya madrasah dapat berwujud dalam berbagai bentuk fisik maupun non fisik. Kemauan yang kuat dari masyarakat untuk mengirim anaknya ke Madrasah juga merupakan salah satu bentuk partisipasi pembuatan regulasi (peraturan) yang dituangkan dalam bentuk undang-undang maupun peraturan daerah merupakan salah satu partisipasi yang lain. Jadi Madrasah dalam memberikan pelayanan pendidikan, tidak akan terlepas dari lingkungan Madrasah itu sendiri.

Hubungan sekolah dengan masyarakat sangat besar manfaatnya bagi pembinaan dukungan moral, material dan pemanfaatan masyarakat sebagai sumber belajar. Madrasah sebagai lembaga di dalam tugas dan fungsinya tidak mungkin melepaskan diri tanpa hubungan dengan masyarakat khususnya orang tua mruid. Hubungan dan komunikasi dengan masyarakat ini sangat penting artinya dalam rangka memberikan pengertian yang baik pada masyarakat. Sehingga dapat diharapkan timbulnya partisipasi yang positif terhadap sekolah. 


\section{B. Landasan Teori}

\section{Partisipasi Orang Tua Murid}

Partisipasi sebenarnya bukan istilah baru dan bukan pula konsep baru bagi masyarakat Indonesia. Konsep partisipasi telah lama dipraktekan oleh berbagai suku dan kebudayaan di Indonesia. Adapun yang dimaksud dengan partisipasi adalah keikutsertaan atau keterlibatan, (Kemenag, 2001:118-119).

Jadi partisipasi orang tua murid keikutsertaan atau keterlibatan orang tua murid pada khususnya dan masyarakat yang ada disekitar Madrasah khususnya di sekitar lingkungan Ml Assa'adah Labuapi Kabupaten Lombok Barat. Pentingnya ikut berpartisipasi dalam kehidupan bermasyarakat antara lain:

a) Merupakan alat untuk merubah citra masyarakat awam terhadap pengertian salah tentang kebijakan sekolah dan para petugas sekolah.

b) Memberikan informasi tentang program dan kebijaksanaan sekolah.

c) Menghilangkan atau mengurangi kritik-kritik tajam terhadap sekolah, (Fuad, 1997:94).

Pendekatan partisipatif belakangan ini diyakini mempunyai keunggulan dibanding dengan pendekatan lainnya.

a. Pendekatan yang selama ini cendrung mengurangi, yang berasal dari atas (top down).

Pembangunan masyarakat yang selama ini dilaksanakan di Indonesia ditekankan pada pendekatan yang bersifat top down, berbagai program pembangunan pendidikan yang lebih diwarnai oleh isntitusi dan pusat tanpa menghiraukan aspirasi yang berkembang di daerah. Keterlibatan masyarakat termasuk guru dan murid sangat minimal bahkan hampir tidak ada program-program tersebut lebih sering diturunkan dari pusat. Berbagai kelemahan pendekatan top down tersebut berakibat pada keberhasilan yang semu dari berbagai program, dalam arti program tersebut tidak dapat bertahan lama dan hanya memiliki dampak pada sebagian kecil dari target program tersebut.

b. Kebutuhan terhadap keikutsertaan masyarakat

Dengan adanya berbagai kelebihan terhadap pendekatan top down tersebut telah melahirkan pendekatan yang lebih berpartisipatif dalam arti pelibatan keikutsertaan masyarakat mulai dilakukan pendekatan ini dikenal dari bawah (Bottom-Up). Melalui pendekatan ini masyarakat dilibatkan secara optimal dari pertama hingga akhirnya program yang diharapkan dapat memberikan manfaat dan membutuhkan mereka dalam program tersebut. Keuntungan dari program ini juga dapat memberikan transfer pengetahuan dan keterampilan kepada masyarakat. Dengan demikian dimasa yang akan datang ketergantungan mereka terhadap pihak luar menjdi berkurang. 
Sebelum penulis menjelaskan, tentang manfaat partisipasi masyarakat, terlebih dahulu penulis akan menguraikan peranan masyarakat terhadap sekolah antara lain:

a) Mendapatkan pengawasan, masyarakat akan terlibat dalam pengawasan terhadap sekolah (Social Control) pengawasan ini terhadap segala gerak-gerik sekolah selaku lembaga pendidikan, pengawasan dapat secara langsung atau lewat Komite Sekolah, atau lewat media massa, demikian juga masukan hasil pengawasan.

b) Bantuan berupa pembiayaan sekolah (gedung, sarana, prasarana) lewat komite sekolah atau secara langsung perorangan/kelompok.

c) Penyediaan tempat untuk penyediaan sekolah atau lapangan sekolah dan lain-lain keperluan sekolah.

d) Penyediaan nara sumber (Resource Person). Berbagai ahli, berbagai bidang, tersedia dari nara sumber, yang dapat dimanfaatkan oleh sekolah di mana diperlukan.

e) Masyarakat sebagai laboraraturium atau sumber belajar yang sangat membantu proses belajar mengajar. Berbagai bidang kehidupan masyarakat dapat dimanfaatkan sebagai sumber belajar/ laboraturium: perusahaan, perkebunan, industri, perumahan dan lainlain, (Fuad, 2005: 104).

Sebelum penulis menguraikan teknik-teknik menggalang partisipasi masyarakat terlebih dahulu penulis akan menjelaskan mengenai hubungan sekolah dengan masyarakat. Sekolah dan masyarakat merupakan partnersip dalam berbagai aktivitas yang berkaitan dengan aspek-aspek pendidikan diantaranya:

(1) Sekolaah dengan masyarakat merupakan satu kebutuhan dalam menyelenggarakan pendidikan dan pembinaan pribadi peserta didik.

(2) Sekolah dengan tenaga kependidikan menyadari pentingnya kerjasama dengan masyarakat, bukan saja dalam melakukan pembaruan tetapi juga dalam menerima berbagai konsekwensi dan dampaknya, serta mencari alternaive pemecahannya.

(3) Sekolah dan masyarakat sekitar memiliki andil dan mengambil bagian serta bantuan dalam pendidikan di sekolah untuk mengembangkan berbagai potensi secara optimal sesuai dengan peserta didik, (Mulyasa 2005: 172).

Menurut pendapat lain disebutkan bahwa sekolah dan masyarakat memiliki hubungan rasional yaitu:

(1) Adanya kesesuain antara fungsi pendidikan yang dimainkan sekolah dengan kebutuhan masyarakat.

(2) Ketetapan sasaran dan target pendidikan yang ditangani oleh sekolah ditentukan oleh keputusan perumusan dan kontrak antara sekolah dan masyarakat.

(3) Keberhasilan penunainan fungsi sekolah sebagai layanan pesanan masyarakat sangat dipengaruhi oleh ikatan obyektif antara sekolah dan masyarakat. I katan obyektif ini dapat berupa perhatian, penghargaan dan bantuan tertentu seperti dana, fasilitas dan 
bantuan lain, baik bersifat ekonomis dan yang memberikan makna penting pada eksistensi dan hasil penting, (Depdiknas dalam Mulyana, 2005: 172).

Sekolah merupakan bagian yang tak terpisahkan dari masyarakat, seperti para orang tua yang tergabung dalam Badan Pembangu Penyelenggara dengan atasan langsung. Demikian pula hasil pendidikan yang berupa lulusan akan menjadi harapan dan dambaan masyarakat. Hubungan sekolah dengan masyarakat merupakan sarana yang sangat berperan di dalam sistem social mengembangkan pribadi peserta didik di sekolah. Sekolah sebagai sistem social merupakan integral dari sistem social yang lebih besar yaitu masyarakat. Sekolah dan masyarakat mempunyai hubungan yang sangat erat dalam mencapai tujuan sekolah atau pendidikan secara efektif dan efisien. Memberdayakan masyarakat dan lingkungannya sangat penting artinya bagi keberlangsungan pendidikan. Menyadari akan hal itu maka sekolah dituntut lebih aktif dan efektif untuk mengembangkan hubungan kerjasama yang lebih harmonis. Ada beberapa pendekatan yang digunakan untuk menggalang partisipasi masyarakat yaitu:

(1) Melibatkan masyarakat dalam berbagai program dan kegiatan di sekolah yang bersifat social kemasyarakatan, seperti bakti social, perpisahan, peringatan hari besar nasional, keagamaan dan pantas seni. Pelibatan masyarakat sesuai dengan hobi, kemampuan dan pekerjaan mereka dengan program dan kegiatan yang akan dilakukan sekolah.

(2) Mengidentfikasikan tokoh masyarakat, yaitu orang-orang yang mampu mempengaruhi pada umumnya. Tokoh tersebut yang pertama kali harus dihubungi, diajak kompromi, konsultasi dan dimintaa bantuan untuk menarik masyarakat berpartisipasi dalam program dan kegiatan sekolah. Tokoh-tokoh tersebut mungkin berasal dari orang tua peserta didik figure masyarakat (Kiyai).

(3) Meliabatkan tokoh masyarakat tersebut dalam berbagai program dan kegiatan sekolah, yang sesuai dengan minatnya. Misalnya olahragawan dapat dilibatkan dalam pembinaan olah raga di sekolah, dokter dapat melibatkan dalam Usaha Kesehatan Sekolah ataupun Palang Merah Remaja. Psikolog dapat dilibatkan dalam kegiatan bimbingan dan penyuluhan. Selanjutnya tokoh masyarakat tersebut dijadikan mediator dengan masyarakat pada umumnya.

(4) Memilih waktu yang tepat untuk melibatkan masyarakat sesuai dengan profesi dan perkembangan masyarakat. Misalnya awal pelibatan Olahragawan dikaitkan dengan kegiatan PORDA, ketika minat masyarakat terhadap olah raga yang sedang meningkat. Awal pelibatan Dokter dimulai pada hari kesehatan Nasional atau pada saat kegiatan disekolah. (Mulyasa, 2005:174).

Dalam rangka memperkenalkan keseluruhan program sekolah bersama masyarakat hendaknya menguntungkan kedua belah pihak. Sehingga masyarakat dapat merasakan manfaat secara langsung jika 
membantu program tersebut. Dalam pendapat lain juga disebutkan, dalam mengggalanng partisipasi masyarakat sekolah dapat:

(1) Melaksanakan program-program kemasyarakatan, misalnya kebersihan lingkungan dan membantu lalu lintas di sekitar sekolah. Program sederhana seperti itu secara perlahan tapi pasti akan menumbuhkan simpati masyarakat.

(2) Mengadakan Open House yang memberi kesempatan masyarakat luas untuk mengetahui program dan kegiatan sekolah. Tentu saja dalam kesempatan semacam itu sekolah perlu menonjolkan program-program yang menarik minat masyarakat.

(3) Mengadakan bulletin sekolah, majalah atau lembar informasi yang secara berkala memuat kegiatan dan program sekolah, untuk diinformasikan kepada masyarakat.

(4) Mengundang tokoh untuk menjadi pembicara atau membina program sekolah, misalnya mengundang Dokter yang tinggal di sekitar sekolah atau orang tua murid untuk menjadi pembicara atau Pembina program kegiatan sekolah.

(5) Membuat program kerja sama sekolah dengan masyarakat, misalnya dalam perayaan nasional dan keagamaan.

(6) Upaya-upaya dalam meningkatkan mutu madrasah, (Mulyasa, 2005: 174).

Sebelum penulis menguraikan upaya-upaya apa yang akan dilakukan dalam meningkatkan mutu Madrasah. Sebelumnya mari kita pahami terlebih dahulu apa pengerti mut secara umum. Mutu secara adalah gambaran dan karakteristik menyeluruh dari barang atau jasa yang menunjukan kemampuannya dalam memuaskan kebutuhan yang ditentukan atau yang tersirat. Dalam konteks pendidikan, pengertian mutu mencakup input, proses dan output, (Kemenag, 2002:13).

a) Klasifikasi dan karakteristik pendidikan yang bermutu

Sebelum penulis menjelaskan klasifikasi pendidikan yang bermutu, maka terlebih dahulu penulis akan menguraikan apa yang dimaksud dengan mutu Madrasah. Mutu Madrasah adalah kemampuan lembaga pendidikan dalam mengelola proses pendidikan yang mencakup input, proses dan Output pendidikan. Memahami pengertian mutu dalam konsep pendidikan tesebut maka dapat dijelaskan bahwa klasifikasi pendidikan yang bermutu dapat dilihat dari tiga unsur Input Proses dan Output pendidikan, (Kemenag, 2002:13).

b) Upaya-upaya dalam meningkatkan Mutu Madrasah

Peningkatan mutu pendidikan tidak akan tercapai apabila tidak ada kerja sama antar sekolah, pemerintah, masyarakat, dan akreditas Madrasah (bagi Madrasah Swasta).

\section{Kaidah Dasar Pendidikan}

Secara kodrati manusia memiliki kecenderungan-kecenderungan baik dalam bakat, minat dan kemampuan dan sebagainya, namun semua 
perangkat tersebut hanya merupakan potensi yang terpendam di dalam jiwa seorang individu, artinya kecenderungan dimaksud hanya akan tetap menjadi kecenderungan belaka tanpa adanya sesuatu wahana yang akan menjembataninya ke dalam dunia nyata. Oleh karena itu, pendidikan merupakan sarana riel dalam kebudayaan manusia diasumsikan dapat merealisasikan potensi-potensi yang terpendam dimaksud. Dengan demikian, pendidikan adalah upaya bagi pemberdayaan kualitas sumber daya yang sesuai dengan nilai-nilai kemanusiaan.

Pada dasarnya pendidikan adalah usaha-usaha untuk mempersiapkan peserta didik agar mampu hidup dengan baik dalam masyarakatnya, mampu meningkatkan dan mengembangkan kualitas hidupnya sendiri serta berkontribusi secara bermakna dalam mengembangkan dan meningkatkan kualitas hidup masyarakat dan bangsanya, (Sudaridja Adiwikarta, 1994: 104).

\section{a. Fungsi dan Tujuan Pendidikan}

Pendidikan dalam dunia modern menjadi salah satu bagian dari kehidupan, sebab tidak ada satupun kelompok masyarakat terdidik yang meragukan fungsi dan peranan pendidikan itu sendiri untuk membawa arus perubahan dalam berbagai aspek kehidupan seperti bidang Ekonomi, Sosial Budaya, Agama Politik, dan sebagainya. Oleh karena itu pendidikan yang baik akan menjadi fundamen yang baik pula untuk menghantarkan masyarakat pada pencapaian tujuan hidup dan kehidupan yang sesuai dengan fitrah kemanusiaannya. Namun demikian, proses pendidikan terkadang menjadi masalah bagi sementara kalangan karena belum memadainya tingkat kesadariannya terhadap nilai guna dari pendidikan itu. Tidak dapat diingkari dari kenyataan yang ada bahwa disatu sisi pendidikan memang merupakan sesuatu faktor penyebab, tetapi disisi yang lain pendidikan dapat sebagai faktor akibat dan pendidikan adalah alat, namun juga adalah tujuan. Dengan demikian, pendidikan merupakan suatu variabel yang syarat dengan berbagai nuansa.

Optimalisasi proses penyelenggaraaan pendidikan pada hakekatnya adalah untuk menunaikan fungsinya dalam konstelasi pengembangan sumber daya manusia, hal ini mengingat bahwa proses pendidikan itu hanya untuk dan terfokus pada pemberdayaan kepribadian individu yang pada akhirnya bermuara pada nilai-nilai kehidupan bermasyarakat, berbangsa, dan bernegara. Jika diperhatikan dari sudut kepentingan masyarakat, maka proses pelaksanaan pendidikan merupakan upaya sadari dari sekelompok masyarakat untuk mengembangkan individu agar ia dapat hidup selaras dengan kepentingan nilai-nilai yang telah diciptakan oleh lingkungan masyarakat itu sendiri, sedangkan apabila dilihat dari kepentingan individu, maka proses pendidikan yang ia peroleh merupakan usaha dari yang bersangkutan untuk mengembangkan diri dalam rangka pencapaian 
tingkat perkembangan yang baik sesuai dengan standar yang ada dalam lingkungan mayarakat itu sendiri.

Keterkaitan antara masyarakat dengan individu bagi proses pendidikan melahirkan beberapa fungsi pendidikan secara umum. Pendidikan itu memiliki beberapa fungsi, yakni:

a) Fungsi pengembangan artinya pendidikan bertanggung jawab mengembangkan potensi individu yang bersifat unik, dimana pendidikan seyogyanya memperkaya keterampilan dalam segi-segi ilmu pengetahuan, penyesuaian diri, filsafat hifup maupun dalam segi pekerjaan. Melalui pendidikan individu memperoleh kesempatan untuk mengembangkan minat, kecakapan dan bakat-bakat khusus yang dimilikinya.

b) Fungsi peragaman artinya keragaman kecakapan, minat dan tujuan siswa terefleksikan di dalam pola kematangan perilakunya. Keragaman ini mengharuskan pendidikan untuk menyediakan program-program yang sesuai dengan kebutuhan individu.

c) Fungsi integrasi, artinya fungsi pengembangan dan peragaman harus diikuti dengan fungsi integrasi. Fungsi ini berkenaan dengan upaya membantu siswa mencapai keterpaduan hidup di dalam masyarakat dengan memiliki identitas diri yang kuat, (Sunaryo Kartadinata dkk, 1998: 12).

Jika disimak tentang ketiga fungsi pendidikan tersebut di atas, maka seharusnya di dalam lembaga pendidikan formal (khususnya dalam system persekolahan) dari tingkat pendidikan dasar sampai jenjang yang tertinggi telah dapat menggali dan menemukan potensi yang dimiliki peserta didiknya untuk dapat memfungsikan pendidikan yang ia terima secara optimal, sesuai dengan bakat, minat dan kecakapan-kecakapan yang ada pada dirinya, sehingga tujuan-tujuan pendidikan dapat tercapai sesuai dengan harapan-harapan baik secara personal maupun dalam skala nasional.

Adapun spesifikasi fungsi pendidikan nasional adalah sebagaimana yang tertuang dalam Undang-Undang Pendidikan Nasiional Nomor 2 Tahun 1989 Pasal 3 yang menyebutkan bahwa Pendidikan Nasional berfungsi untuk mengembangkan kemampuan serta meningkatkan mutu kehidupan dan Martabat Manusia Indonesia dalam rangka upaya mewujudkan Tujuan Nasional, (UU Pendidikan, 2006:3). Untuk dapat memfungsikan Pendidikan Nasional tersebut, maka fungsi-fungsi bersifat umum di atas tidak dapat diabaikan dalam pelaksanaannya, sebab titik tolaknya harus melalui individu untuk mencapai fungsi pendidikan yang bersifat Nasional dimaksud.

Sebagai suatu kegiatan yang terencana dan sistematis, maka proses pendidikan yang diselenggarakan hanya untuk dan atau diorientasikan pada tujuan-tujuan yang telah disepakati dan ditetapkan bersama, baik dalam lingkup instruksional, institusional maupun dalam lingkup nasional. Namun demikian, penjabaran-penjabaran tujuan pendidikan pada masing-masing tahapan seperti yang tercermin itu

$$
\text { 90|Edisi } 2 \text { No.1 Januari } 2020
$$


hanya semata-mata diarahkan untuk mencapai Tujuan Pendidikan Nasioanal, artinya ruang lingkup yang terurai dalam tahapan yang paling ujung (misalnya tujuan pengajaran) harus mendukung tujuan pada tahapan berikutnya (tujuan lembaga) dan akhirnya harus mendukung Tujuan Pendidikan Nasional. Tujuan Pendidikan Nasional yang telah digariskan itu seperti yang teranngkum dalam kutipan di bawah ini:

Pendidikan Nasional bertujuan mencerdaskan kehidupan manusia dan mengembangkan manusia Indonesia seutuhnya, yaitu manusia yang beriman dan bertaqwa terhadap Tuhan Yang Maha Esa dan berbudi pekerti luhur, memiliki pengetahuan dan ketrampilan kesehatan jasmani dan rohani, kepribadian yang mantap dan mandiri serta rasa tanggung jawab kemasyarakatan dan kebangsaaan, (UU No. 2 Tahun 2006 Pasal 4:6).

Apabila tujuan umum pendidikan nasional sebagaimana yang tertuang dalalm undang-undang pendidikan tersebut, tampak bahwa pendidikan di Indonesia bertujuan membantu mengembangkan totalitas kepribadian atas dasar ketaqwaan terhadap Tuhan Yang Maha Esa. Secara tersurat maupun tersirat bahwa tujuan Pendidikan Nasional mengisyaratkan bahwa aspek fisik, social, kognitif, afektif, dan konatif adalah faktor-faktor keperibadian yang harus dikembangkan melalui upaya pendidikan pengembangan semua aspek tadi harus terintegrasi dalam ketaqwaan terhadap Tuhan Yang Maha Esa. Dengan kata lain bahwa melalui pendidikan warga negara dibantu untuk mencapai tahap kehidupan yang bermakna secara menyeluruh. Secara universal, tujuan pendidikan ini dapat dijelaskan sebagai berikut: Secara ringkas dapat di sebut, bahwa tujuan pendidikan sebagai berikut:

a) Bisa membawa anak manusi pada pengertian hakekat diri sendiri, membangun kemanusiaan dan melaksanakan misi hidup masingmasing. Ringkasnya menjadi manusia yang baik.

b) Mengantar anak didik ke dalam dunia peradaban yang terus menerus dan dinamis, jadi membangun tipe manusia pembanguun yang rajin, ulet, berani, jujur, dan cocok dengan zamannya, (Kartini Kartono, 1991:14).

\section{Metode Penelitian}

Pada setiap penelitian mengharuskan adanya pendekatan yang menunjukan rencana, cara mengumpulkan data dan analisis data. Oleh karena itu untuk mendapatkan data dan informasi yang terkait dalam penulisan skripsi ini maka penulis menggunakan suatu pendekatan penelitian yang disebut penelitian kualitatif, karena data yang diperoleh dilapangan cendrung bersifat informasi-informasi lisan maupun tulisan.

Berhubungan dalam penulisan ini, penulis menggunakan pendekatan kualitatif, maka penulis mengkaji setiap pristiwa, aktivitas kerja dan hal-hal lain yang berhubungan dengan partisipasi orang tua dalam meningkatkan

$$
\text { 91|Edisi 2 No.1 Januari } 2020
$$


kualitas MI Assa'adah Labuapi Kabupaten Lombok Barat Provinsi Nusa Tenggara Barat untuk mendalami fokus yang diteliti dan kemudian mendeskripsikan secara mendetail.

Adapun ciri-ciri utama penelitian kualitatif antara lain sebagai berikut: (1) Latar alamiah, (2) Manusia sebagai alat (instrument), (3) Metode kualitatif, (4) Analisis data secara induktif, (5) Teori dari dasar (Grounded theory), (6) Desktiptif, (7) Lebih mementingkan proses dari pada hasil, (8) Adanya batas yang ditentukan oleh fokus adaanya keriteria khusus untuk keabsahan data, (9) Desain yang bersifat sementara, (10) Hasil penelitian dirundingkan dan di sepakati bersama, (Moleong, 2005:813).

Oleh sebab itu dalam penelitian ini mencerminkan persfektif fenomonologis artinya penelitian ini berusaha untuk memahami makna dari peristiwa-peristiwa, aktivitas-aktivitas kerja, interaksi individual dalam situasi tertentu untuk memahami bagaimana dan apa makna yang mereka konstruksikan dalam setiap peristiwa dan aktivitas kerja dalam kehidupan mereka.

Sumber data dalam penelitian ini dilakukan secara purposive dengan menggunakan teknik sampling dengan mengambil beberapa sample sebagai responden, kepala sekolah, staf guru, orang tua murid, pengurus yayasan Ml Assa'adah Labuapi Kabupaten Lombok Barat Provinsi Nusa Tenggara Barat. J umlah responden sesuai dengan data yang diinginkan dan tidak semua strata responden disesuaikan dengan data yang diinginkan dan tidak semua strata responden harus dihadirkan dalam pengambilan data.

\section{Temuan Penelitian}

\section{Partisipasi orang tua murid dalam meningkatkan kwalitas MI Assa'adah Labuapi Kabupaten Lombok Barat}

Berdasarkan hasil observasi dan wawancara dari tanggal 02 September sampai tanggal Desember 2019 terhadap beberapa wali murid guru dan pihak Yayasan, maka penulis memperoleh beberapa dan antara lain: Menurut Umar, S.Pd. selain Kepala Sekolah MI Assa'adah Labuapi Kabupaten Lombok Barat, bahwa ada 4 faktor yang mempengaruhi mutu pendidikan antara lain. Pertama adanya sarana dan prasarana yang dimiliki oleh sekolah untuk menunjang proses belajar mengajar. Kedua kwalitas guru yang dimiliki oleh sekolah. Ketiga faktor dari diri siswa itu sendiri, khususnya kemampuan dasar siswa. Keempat tongkat Aspirasi masyarakat, termasuk orang tua murid terhadap arti pentingnya pendidikan.

1) Orang tua murid/masyarakat ikut serta dalam pembiayaan dana Madrasah

Menurut Umar, S.Pd. selaku Kepala Sekolah MI Assa'adah Labuapi Kabupaten Lombok Barat, menyatakan bahwa Partisipassi orang tua murid ataupun masyarakat merupakan salah satu penunjang keberhasilan pendidikan siswa/siswa terutama siswa/siswi Ml Assa'adah Labuapi Kabupaten Lombok Barat Provinsi Nusa Tenggara Barat, pada khususnya dan siswa/siswi Madrasah lain pada umumnya, dengan 
partisipassi masyarrakat/orang tua murid sangat-sangat diharapkan dan sudash menjadi kewajiban. Berbagai upaya pemerintah telah diusahakan agar masyarakat menyadari begitu sangat berartinya ikut berpartisipasi demi masa depan sekolah dan majunya pendidikan. Dukungan partisipasi dari masyarakat sangat-sangat di butuhkan tanpa adanya dukungan masyarakat maka sebuah lembaga pendidikan tidak akan bisa berjalan dengan baik, dengan adanya partisipasi/dukungan masyarakat maka segala kebutuhan kebutuhan sekolah dapat terpenuhi baik berupa penambahan sarana-prasararana, penambahan gedung belajar penambahan tenaga guru sebagai penunjang dalam proses belajar mengajar.

Adapun dana yang di dapat tersebut digunakan untuk kebutuhan Madrasah. Dana Madrasah digunakan antara lain:

a. Pembelian alat-alat tulis kantor

b. Pembelian alat-alat kantor (Mesin tik, lemari dan lain-lain).

c. Gaji guru

d. Pengembangan perpustakaan

e. Pembangunan sarana fisik

f. Penigkatan professional guru

g. Pembelian alat-alat peraga sebagai penunjang PBM

h. Biaya perbaikan/pemeliharaan gedung, pagar dan pekarangan Madrasah.

i. Membina kegiatan siswa (pesantren kilat, karya tulis dan lain-lain).

j. Biaya linstrik, air dan lain-lain. (Umar, S.Pd, wawancara 26 September 2019).

2) Orang tua mengontrol anak belajar di ruang.

Menurut Bapak H. Hambali selaku pimpinan Yayasan Ponpes Assa'adah Islamiyah menyatakan bahwa keikut sertaan masyarakat/ merupakan bukti yang nyata bagi orang tua murid untuk bisa memotivasi putra putrinya, ikut membantu tegaknya disiplin Madrasah, melengkapi semua keperluan belajar untuk putra putrinya dan ikut memberikan perhatian terhadap perkembangan situasi pendidikan di madrasah. (TGH. M. Syukri J unaidi, S.Pd.I, Wawancara 26 September 2019).

Menurut Mustamin orang tua murid MI Assa'adah Labuapi Kabupaten Lombok Barat Provinsi Nusa Tenggara Barat, menyatakan bahwa orang tua adalah orang yang paling dekat, tauladan pendidik utama pertama bagi putra putrinya, karena melalui orang tualah anak itu mengenal Tuhan Allah yang kita sembah, mengamalkan ajaran-ajaran agama, mengenalkan nama-nama nabi, malikat dan sebagainya. Sikap orang tua keperibadian dan cara-cara hidup merupakan unsur-unsur pendidikan yang berlangsung di rumah orang tua sebagai pendidik utama mengontrol anak belajar, membantu anak belajar sehingga kesulitan yang dihadapi di sekolah bisa dipecahkan, agar mendapatkan prestasi yang diharapkan bisa tercapai dengan hasil yang memuaskan, bakat serta minat anak harus dikontrol terus menerus dengan tujuan agar orang tua bisa mengetahui kemana anak harus diarahkan, orang 
tua membimbing anak belajar dirumah merupakan bukti nyata dari partisipasi orang tua murid khususnya orang tua murid MI Assa'adah Labuapi Kabupaten Lombok Barat.

3) Melengkapi Buku Pelajaran

Menurut Mustamin orang tua Ml Assa'adah Labuapi Kabupaten Lombok Barat menyatakan Sikap orang tua menghendaki anaknya berhasil maju dan berpendidikan, oleh karena itu untuk mewujdukan keinginannya ini orang tua melengkapi buku pelajaran yang dibutuhkan oleh anak didik agar prestasi yang diinginkan bisa terwujud, karena dengan membaca, cakrawala pengetahuan anak didik akan semakin luas dengan tersedianya buku pelajaran anak bisa belajar sendiri di rumah dengan dibimbing orang tua masing-masing, (Serehen Efendi, S.Pd, Wawancara 27 September 2019).

4) Konsultasi antara orang tua dengan sekolah mengenai perkembangan anak didik

Menurut Bukhari sekretaris Yayasan Ponpes Tarbiyah Islamiyah menyatakan bahwa hubungan antara sekolah dan orang tua hendaklah terus dibina, dikembangkan, dan dipertahankan, pihak sekolah mengadakan kunjungan rumah orang tua murid. Memberikan informasi tentang perkembangan anak didik mereka, tentang perkembangan prestasi belajar putra-putri mreka, apakah putra-putrid mereka lamban dalam menerima pelajaran agar mereka cepat menerima pelajaran laporan orang tua yang disampaikan oleh guru, pihak sekolah memberikan penjelasan tentan kelemahan-kelemahan dan tentang prestasi yang dicapai sebagai putra-putri mereka, melalui penyerahan buku laporan pendidikan (Raport) pihak sekolah mengkonsultasikan perkembangan prestasi belajar mereka dimana pembagian raport diserahkan pada setiap selesai semester dan kenaikan kelas, dari nilai yang dicantumkan di buku raport orang tua bisa mengetahui dan menganalisa perkembangan prestasi belajar putra-putrinya apakah terjadi penurunan atau peningkatan prestasi.

5) Orang Tua Melengkapi Pasilitas Belajar Anak

Menurut Serehen Efendi, S.Pd. guru MI Assa'adah Labuapi Kabupaten Lombok Barat menyatakan setiap para orang tua selain melengkapi buku-buku pelajaran orang tua juga melengkapi pasilitas belajar anak seperti seragam sekolah, alat tulis menulis, alat hitung dan lain-lain sebagai penunjang dalam proses belajar mengajar, (Serehen Efendi, S.Pd. Wawancara 27 September 2019).

2. Kendala-Kendala dan upaya mengatasinya yang dihadapi dalam meningkatkan kwalitas MI Assa'adah Labuapi Lombok Barat

\section{a. Kendala yang dihadapi}

Berdasarkan hasil wawancara dan observasi dari tanggal 22 September samapi dengan 30 Desember 2019 terhadap beberapa wali murid guru, dan pihak Yayasan, maka penulis memperoleh data antaraa lain sebagai berikut: 
1) Guru tenaga pengajar yang dimiliki tidak seimbang melihat guru negrinya hanya satu orang selainnya guru honorer dan sebagainya belum memnuhi kwalifikasi mengajar dan jumlah siswanya banyak mampu bersaing dengan Madrasah atau sekolah lain yang ada di Pemalikan, (Observasi, 27 September 2019).

1) Orang Tua Murid

Menurut Serehen Efendi, S.Pd. Guru Ml Assa'adah Labuapi Kabupaten Lombok Barat menyatakan bahwa sebagian dari orang tua murid yang masih belum sadar arti pentingnya pendidikan, masih ada diantara orang tua murid yang tidak memperhatikan dan kurang mendorong anaknya untuk belajar di rumah, disebabkan kurangnya ilmu pengetahuan orag tua dan ekonomi lemah.

2) Siswa

Dilihat dari input siswa yang diterima di MI Assa'adah Labuapi Lombok Barat rata-rata tidak berpendidikan TK dan sebagian besar berlatar belakang ekonomi sedang kebawah, walaupun sebagian besar siswanya tidak berlatar belakang pendidikan TK namun mereka mampu bersaing denggan sekolah-sekolah yang ada di Desa Labuapi Lombok barat dalam hal prestasi.

3) Pasilitas sarana dan prasarana

Menurut Serehen Efendi, S.Pd. Wakil Kepala Sekolah MI Assa'adah Labuapi Kabupaten Lombok Barat menyatakan bahwa Ml Assa'adah Labuapi Kabupaten Lombok Barat memang bukan termasuk Madrasah yagn sangat maju tapi Ml Assa'adah Labuapi Lombok Barat masih mampu bersaing dengan sekolah-sekolah yang ada di Desa Labuapi walaupun pasilitas sarana dan prasarana masih kurang mendukug, seperti madrasah masih kekurangan ruang untuk ruang perpustakaan, Aula, Musholla yang mana ruang-ruang tersebut masih digabung akan tetapi pihak sekolah terus optimis untuk lebih maju dari sebelumnya, (Serehen Efendi, S.Pd., Wawancara 27 September 2019).

\section{b. Upaya mengatasi kendala tersebut}

Sebagai Madrasah yang memiliki berbagai kendala-kendala dalam meningkatkan kwalitas, tentu memiliki upaya untuk mengatasi kendala yang dihadapi adapun upaya MI Assa'adah Labuapi Kabupaten Lombok Barat Provinsi Nusa Tenggara Barat dalam mengatasi kendala tersebut di atas adala sebagai berikut:

1) Guru

Menurut kepala sekolah menyatakan bahwa guru yang mengajar di MI Assa'adah Labuapi Kabupaten Lombok Barat, sebagian ada yang kejuruan dan ada yang non kejuruan. Adapun upaya yang dilakukan bagi yang berijazah non kejuruan telah mengikuti penataran sebagai upaya sekolah untuk meningkatkan kwalitas Guru MI Assa'adah Labuapi Kabupaten Lombok Barat, (Serehen Efendi, S.Pd., Wawancara 27 September 2019).

2) Siswa 
Kita ketahui bahwa input siswa yang ada di Ml Assa'adah Labuapi Kabupaten Lombok Barat sebagian besar tidak berpendidikan TK dan terdiri darri golongan ekonomi sedang kebawah hal ini tidask mengendorkan semangat kita untuk meningkatkan mutu pendidikan karena siswa merupakan salah satu komponen mutu pendidikan. Maka upaya-upaya kami untuk meningkatkan mutu adalah selain belajar pada jam-jam sekolah Ml Assa'adah Labuapi Kabupaten Lombok Barat mengadakan kegiatan ekstrakurikuler seperti pesantren kilat yagn diadkan 2 kali sebulan dimana didalamnya diadakan kegiatan berupa pembinaan shalat-shalat sunat seperti shalat tahajjud, istiharah dan cara-cara beribadah waajib dan ibadah sunat lainnya dan lain-lain selain itu juga Ml Assa'adah Labuapi Lombok Barat juga mengadakan les-les untuk menutupi kekurangan materi pelajaran yang telah disampaikan.

\section{Pembahasan}

\section{Partisipasi orang tua murid dalam meningkatkan kwalitas MI Assa'adah Labuapi}

Partisipasi orang tua murid dalam meningkatkan kwalitas MI Assa'adah Labuapi Kabupaten Lombok Barat Provinsi Nusa Tenggara Barat Tahun Pelajaran 2019-2020.

Dari data yang telah dipaparkan maka partisipasi orang tua ataupun masyarakat sangat dibutuhkan karena dengan partisipasi masyarakat segala kebutuhan sekolah atupun kepentingan sekolah yang belum ada/belum lengkap dapat ditunjang/atau di Bantu oleh msyarakat karna keterkaitan MI Assa'adah Labuapi Kabupaten Lombok Barat dengan masyarakat merupakan kunci keberhasilan sekolah.

Hubungan masyarakat dengan Ml Assa'adah Labuapi Lombok Barat dapat ditunjukan untuk mencapai beberapa hal di bawah ini:

a. Terbukanya kesempatan bagi masyarakat untuk mengevaluasi proses pendidikan, memungkinkan munculnya partisipasi masyarakat sekitar dan khususnya orang tua peserta didik dalam pelaksanaan pendidikan.

b. Mengingat tempat tinggal siswa dan sekolah tidak berjauhan maka hal ini akan dapat menimbulkan sinkronisasi antara kegiatan sekolah dengan kegiatan kemasyarakatan, sehingga peserta didik bisa belajar dari menyerap kehidupan darri masyarakatnya.

c. Partisipasi masyarakat ataupun orang tua hasil dalam pembiayaan dana yang mana dana tersebut dapat diperoleh dari pemerintah maupun para donator yag dipergunakan untuk keperluan Madrasah baik itu gaji guru, pembelian alat-alat kantor, pembangunan prasarana fisik.

Hubungan Ml Assa'adah Labuapi Kabupaten Lombok Barat dengan masyarakat merupakan seluruh proses kegiatan sekolah yang di rencanakan dan diusahakan secara sengaja dan bersungguh-sungguh serta pembinaan secara kontinyu untuk mendapatkan simpati dari masyarakat pada umumnya, khususnya masyarakat yang berkepentingan langsung dengan sekolah sehingga kegiatan operasional sekolah/ pendidikan semakin efektif

$$
\text { 96| Edisi 2 No.1 Januari } 2020
$$


dan efesien demi membantu terciptanya tujuan yang telah ditetapkan, pada hakekatnya MI Assa'adah Labuapi Kabupaten Lombok Barat Provinsi Nusa Tenggara Barat merupakan bagian yang tak terpisahkan dengan masyarakat khususnya publiknya seperti para orang tua murid, karena sama-sama memiliki peranan yang amat penting dalam hal pembinaan dan pengembangan pribadi peserta didik. Oleh sebab itu hasil pendidikan pelaksanaan sekolah merupakan dambaan dan harapan bagi masyarakat, maka seluruh kegiatan sekolah juga menjadi tanggung jawab bersama antara pemerintah, masyarakat dan orang tua.walaupun demikian orang tua berperan sebagai pembantu penyelenggara pendidikan dan tidak berhak untuk mempengaruhi apalagi untuk mengubah arah sasaran pendidikannya.

Kemampuan kepala sekolah sebagai leader tercermin dari salah satu sifat leadernya yaitu kemampuannya berkomunikasi secara lisan dengan orang tua murid dan masyarakat sekitar lingkungan sekolah. Hal inilah yang menjadi simfati masyarakat. Semua ini tidak terlepas dari keterbukaan pihak sekolah serta terik-teriknya mengadakan pendekatan yang bertujuan untuk manarik orang tua murid dan simpati dan menumbuhkan partisifasi masyarakat pada umumnya dan khususnya di lingkungan MI Assa'adah Labuapi Kabupaten Lombok Barat. Keterbukaan ini hendaknya selalu di pupuk dan dipertahankan agar pengelolaan terhadap hubungan dengan masyarakat harus dapat dilakukan secara optimal. Demi terwujudnya keterbukaan tersebut, dibutuhkan suatu program yang kreatif dan inovatif dari berbagai pengalaman menunjukkan bahwa sekolah yang memiliki nama yang baik atau kualitas pembelajarannya selalu lebih mapan atau lebih banyak mendapatkan dukungan dari masyarakat, sedangkan sekolah yang tidak mendapat dukungan dari masyarakatnya akan secara berangsurangsur mati. Akan tetapi setelah dicermati dan dianalisa ternyata partisipasi di lingkungan MI Assa'adah Labuapi Kabupaten Lombok Barat Provinsi Nusa Tenggara Barat belum terliat sempurna karena hanya sebagian saja yang mengerti bagaimana pentingnya partisipasi demi keberlangsungan pendidikan bagi anak-anak mereka.

a. Ketaatan siswa Ml Assa'adah Labuapi Kabupaten Lombok Barat Provinsi Nusa Tenggara Barat dalam mematuhi tata tertib.

MI Assa'adah Labuapi Kabupaten Lombok Barat Provinsi Nusa Tenggara Barat dalam kehidupannya sehari-hari selalu menekankan siswanya tentang pentingnya saling tolong menolong sifat kebersamaan dan bergotong royong, saling tolong menolong untuk mengatasi kebutuhan bersama. Sebagaimana sekolah lain MI Assa'adah Labuapi Kabupaten Lombok Barat Provinsi Nusa Tenggara Barat juga memiliki jadwal belajar mengajar di mulai dari Jam 7.15 sampai dengan jam 13.30 wita itu dilaksanakan secara rutin, begitu juga dengan kegiatan diniah dilaksanakan setiap hari minggu, kegiatan ini diisi dengan di awali membaca yasinan bersama setelah itu membahas kitab-kitab kecil. Sedangkan hari rabu dan kamis menghafal ayat-ayat pendek, dalam kehiudupan sehari-hari kegiatan ini di pandu oleh para guru, kegiatan ini bertujuan untuk melatih para siswa membiasakan dalam membaca Al- 
Qur'an, membina ahlaq mereka dan melatih siswa tentang tata cara shalat yang betul.

b. Optimisme Ml Assa'adah Labuapi Kabupaten Lombok Barat dalam menghadapi tantangan dan hambatan kedepan.

Dalam kondisi yang seperti sekarang ini, lapangan pekerjaan semakin sulit dan tingkat pengangguran semakin tinggi tentunya jaminan pekerjaan merupakan faktor yang harus dimiliki oleh sebuah lembaga pendidikan, sebagian besar madrasah saat ini dianggap belum mampu memberikan jaminan kerja sebagaimana lembaga pendidikan lainnya, dalam kendisi seperti ini masyarakat dihadapkan pada dua pilihan aapakah anak-anak mereka dengan harapan membina moral anak-anak mereka akankah lembaga pendidikan lain dengan harapan lapangan pekerjaan yang layak oleh sebab itu madrasah dituntut untuk tidak hanya memberikan nilai-nilai agama daan mebina moral saja, namun juga memberikan materi-materi pendidikan pengembangan teknologi tepat guna, hal ini telah di tanggapi oleh Ml Assa'adah Labuapi Lombok Barat, upaya terus di lakukan dengan harapan keluaran MI Assa'adah Labuapi Lombok Barat benar-benar bermanfaat bagi lingkungan sekitarnya. Namun dalam upaya tersebut tentu saja tidak akan pernah luput dari kesulitan dan hambatan.

Sarana dan prasarana yang masih sangat sederhana walaupun bentuk bangunannya sudah dikatakan cukup memadai namun bangunan itu masih sangat sederhana terlihat dari segu fungsi bangunan tersebut ruang kelas sebanyak 6 ruang sudah cukup digunakan oleh murid lengkap dengan meja kursi namun karna jumlah ruangan di $\mathrm{Ml}$ Assa'adah Labuapi Kabupaten Lombok Barat kurang maka sekolah menggabungkan antara ruangan perpustakaan dengan kelas satu, tentunya ini mengganggu aktivitas guru apabila murid ingin membaca buku meminjam buku di perpustakaan sehingga pihak sekolah membuatkan jadwal bagi siswa yang ingin membaca dan meminjam buku di perpustakaan tujuannya agar siswa tidak berjubel di karenakan kondisi tidak menampung. Dalam hal ini upaya MI Assa'adah Labuapi Kabupaten Lombok Barat untuk meningkatkan sarana fisiknya adalah menanggulangi kesulitan berupa dana, trik-trik kepala sekolah yoang mengadakan pendekatan terhadap masyarakat/ wali murid adalah harapan yang tak pernah putus, yang tujuan dari pada pendekatan tersebut adalah untuk meningkatkan partisipasi masyarakat dalam upaya perbaikan marasah dan melengkapi sarana dan prasarana dalam menunjang proses belajar mengajar di MI Assa'adah Labuapi Kabupaten Lombok Barat.

\section{a. Tenaga Pengajar}

Tenaga pengajar yang di Ml Assa'adah Labuapi Kabupaten Lombok Barat apa beda dilihat dari latar belakang pendidikan yang dimiliki maka sebagian besar tenaga pengajar di MI Assa'adah Labuapi Kabupaten Lombok Barat Provinsi Nusa Tenggara Barat berijazah D2 dan ada beberapa orang yang belum memiliki kwalifikasi mengajar seperti yang 
telah di tentukan oleh undang-undang yang berlaku. Melihat kenyataan seperti ini maka tenaga pengajar yang di miliki oleh Ml Assa'adah Labuapi Kabupaten Lombok Barat digolongkan sedikit dan kwalitas guru belum maksimal digolongkan sedikit karena hanya mempunyai 2 orang guru negeri dan yang lainnya guru honorer. Oleh karena itu Ml Assa'adah Labuapi Kabupaten Lombok Barat berusaha meminta tenaga pengajar yang menguasai bidang kependidikan kepada instansi terkait.

Adapun syarat-syarat seorang pendidik yang tlah di cantumkan dalam undang-undang tentang sistem pendidikan nasional No.20 tahun 2003 BAB XI pasal 49 yang berbunyi: pendidik harus memiliki kwalifikasi minimum dan sertifikasi sesuai dengan jenajang kewenangan mengajar sehat jasmani dan rohani, serta memiliki kemampuan untuk mewujudkan tujuan pendidikan nasional, (Shaleh, 2004:331).

\section{b. Kegiatan Ekstrakurikuler}

Kesadaran berbangsa dan bernegara serta meningkatkan nilai-nilai keperibadian moralitas budi pekerti yang luhur sserta meningkatkan iman dan nilai-nilai ibadah adlah tujuan utama dari kegiatan ekstrakurikuler yang dilaksanakan oleh Ml Assa'adah Labuapi Kabupaten Lombok Barat Provinsi Nusa Tenggara Barat pelaksanaan program ekstra di samping dilaksanakan di sekolah diluar jam-jam yang di jadwalkan lebih banyaak dilaksanakan diluar sekolah sehingga dalam pelaksanaannya lebih banyak melibatkan partisipasi masyarakat. Sadarnya masyarakat/orang tua tentang arti pentingya partisipasi untuk berkelangsungan pendidikan anak-anak mereka merupakan bukti nayata bagi MI Assa'adah Labuapi Kabupaten Lombok Barat dalam upaya meningkatkan kwalitas madrasah. Keluarga merupakan lingkungan pertama dan utama untuk membentuk keperibadian watak mengenal nilai dan norma sebagaimana telah dijelaskan dalam Al-Qur'an surat AtTahrim ayat 6 yang artinya: Hai orang-orang yang beriman, peliharalah dirimu dan keluargamu dari api neraka yang bahan bakarnya adalah manusia dan batu; penjaganya malaikat-malaikat yang kasar, keras, dan tidak mendurhakai Allah terhadap apa yang diperintahkan-Nya kepada mereka dan selalu mengerjakan apa yang diperintahkan.

\section{Kendala-kendala yang dihadapi dan upaya mengatasinya}

Kendala-kendala yang dihadapi dan upaya mengatasinya madrasah MI Assa'adah Labuapi Kabupaten Lombok Barat adalah madrasah yang termuda diantara 2 SD yang ada di Desa Labuapi dan berkembang diantara masyarakat yang mempunyai karakteristik yang berbeda-beda, tentu tidak akan pernah terlepas dari kendla-kendala yang dihadapi di dalam meningkatkan kualitas madrasah dan untuk bisa bersaing dengan madrasah lain.

MI Assa'adah Labuapi Kabupaten Lombok Barat merupakan salah satu Ml yang diminati oleh masyarakat di sekitar lingkungan kediri, oleh sebab itu madrasah mengupayakan untuk mengatasi setiap kendala tersebut dengan mengirim guru-guru untuk mengikuti pelatihan atau

$$
\text { 99|Edisi 2 No.1 Januari } 2020
$$


panataran sebagai upaya untuk meningkatkan kwalitas madrasah, renovasi ruang belajar, membuat gedung perpustakaan secara khusus (sendiri), akan tetapi sampai sekarang keadaan gedung maupun meubleir belum terlihat sempurna karena masih ada sebagian dari meubleir yang rusak ringan.

Dari sekian banyak kendala yang dihadapi oleh MI Assa'adah Labuapi Kabupaten Lombok Barat tidak akan pernah membuat madrasah ini harus mundur. Bahkan kendala inilah yang akan membuat MI Assa'adah Labuapi Kabupaten Lombok Barat ingin maju dan terus bersaing dengan madrasaah-madrasah lain maupun SD yang ada di lingkungannya. Walaupun keberadaan Ml Assa'adah Labuapi Kabupaten Lombok Barat tergolong masih berkembang, namun MI Assa'adah Labuapi Kabupaten Lombok mampu bersaing dengan MI-MI yang ada di Desa Labuapi Kabupaten Lombok Barat telah berhasil dalam upaya meningkatkan kwalitas madrasah, walaupun masih banyak hambatan-hambatan yang dihadapi namun MI Assa'adah Labuapi Kabupaten Lombok Barat tetap optimis untuk menyongsong masa depannya.

\section{E. Kesimpulan}

Secara umum Ml Assa'adah Labuapi Kabupaten Lombok Barat, dinilai cukup berhasil dalam menyadarkan masyarakat sebagaimana arti pentingnya berpartisipasi untuk melaksanakan pendidikan putra-putrinya mereka, untuk lebih jelasnya penulis akan uraikan beberapa kesimpulan berikut:

1. Partisipasi orang tua murid merupakan salah satu penunjang keberhasilan sebuah lembaga pendidikan madrasah dengan berbagai upaya pendekatan yang dilakukan oleh kepala sekolah hingga partisipasi masyarakat/orang tua murid MI Assa'adah Labuapi Kabupaten Lombok Barat sangat baik mereka berupaya sebisa mungkin untuk menjadikan madrasah ini tetap dan lebih baik, banyak upaya yang dilakukan madrasah orang tua murid dapat diwujudkan dalam berbagai bentuk, seperti membantu perbaikan madrasah, membuat gedung perpustakaan baik itu berupa bantuan tenaga, uang atau bahan-bahan bangunan lainnya, selain itu orang tua juga membantu anak-anak belajar di rumah dengan memenuhi kebutuhan anak-anak mereka serta membimbingnya belajar.

2. Adapun kendala yang dihadapi oleh MI Assa'adah Labuapi Lombok Barat adalah jumlah guru yang tidak seimbang dengan jumlah murid karena guru negerinya hanya satu orang selainnya guru honorer, sarana dan prasarana kurang memadai seperti bangku sebagian ada yang rusak ringan dan keadaan ruangan belum tertata dengan baik mushalla dan aula masih bergabung dengan lembaga lainnya. Akan tetapi ini bukanlah suatu kendala yang berarti bagi MI Assa'adah Labuapi Lombok Barat kendala yang dihadapi tidak akan pernah membuat madrasah ini mundur namun semakin bertekad untuk maju dan mampu bersaing dengan SD 


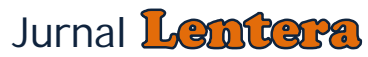

Jurnal Studi Pendidikan

Negeri ada dilingkungan madrasah maupun lingkungan pondok pesantren sekitarnya. 


\section{DAFTAR PUSTAKA}

Arikunto, Suharsimi, 2006. Prosedur Peneltian Suatu Pendekatan Praktik Edisi Revisi VI, Jakarta: Rineka Cipta.

Arikunto, Suharsimi, 1996 Prosedur Penelitian Suatu Pendekatan Praktik. Rineka Cipta, J akarta.

Kemenag. RI. 2001. Pedoman Pengawasan Untuk Madrasah dan Sekolah Umum. CV. Mekar Jaya, J akata.

Hadi, Sutrisno, 2002. Metodologi Research. Andi Yogyakarta.

I hsan, Puad, 2005. Dasar-dasar Kependidikan. Rineka Cipta, J akarta.

Mulyasa, E, 2005, Menjadi Kepala Sekolah Profesional. Rineka Cipta, Jakarta.

Moleong, Lexi, Metode Penelitian Kualitatif. Rosda Karya Bandung.

Poerwadarminta, WJS. 1996 Kamus Umum Bahasa Indonesia. Jakarta: Balai Pustaka.

Riyanto, Yatun, 2001. Metodologi Penelitian Pendidikan.SIC. Surabaya.

Shaleh Abdul Rahman, 2000. Pendidikan Agama dan Keagamaan. Gema Windu Panca Perkasa J akarta.

Sidi J ati, Indra, 2003. Menuju Masyarakat Belajar Menggagas Pradigma Baru Pendidikan. Rineka Cipta, J akarta.

Shaleh, Abdul Rahman, 2000. Madrasah dan Pendidikan Anak Bangsa. Raja Grapindo. Jakarta.

Tim Dosen FIP-IKIP Malang. 1990. Pengantar Dasar-Dasar Pendidikan. Surabaya: Usaha Nasional.

Undang-Undang Sistem Pendidikan Nasional (UU RI No.20 Tahun 2003). 2006. Bandung: Fokusmedia.

Uzer Usman, 2003. Menjadi Guru Profisional, Bandung: Rosda Karya.

Winarno Surahmad, 1990, Pengantar Intraksi Belajar Mengajar, Bandung: Transito

Zuhairini, dkk. 1997. Metode Khusus Pendidikan Agama, Surabaya: Usaha Nasional 